"This is the peer reviewed version of the following article: [J. Am. Chem. Soc. 2020, 142, 19047-19051] which has been published in final form at [Link to final article using the DOI: https://dx.doi.org/10.1021/jacs.0c09814]. This article may be used for non-commercial purposes in accordance with the American Chemical Society Terms and Conditions for Self-Archiving."

\title{
The photochemical synthesis of a stable terminal uranium(VI) nitride
}

\author{
Luciano Barluzzi, Rosario Scopelliti, and Marinella Mazzanti * \\ Institut des Sciences et Ingénierie Chimiques, Ecole Polytechnique Fédérale de Lausanne (EPFL), 1015 Lausanne, \\ Switzerland
}

\begin{abstract}
Terminal uranium nitrides have so far proven impossible to isolate by photolysis of azides. Here we report the second ever example of an isolated terminal uranium(VI) nitride. We show that the terminal nitride $\left[\mathrm{NBu}_{4}\right]\left[\mathrm{U}\left(\mathrm{OSi}\left(\mathrm{O}^{\mathrm{t} B u}\right)_{3}\right)_{4}(\mathrm{~N})\right], 3$ can be prepared upon photolysis with UV light of the U(IV) azide analogue. This is achieved by careful tailoring of the azide precursor and of the reaction conditions. Complex $\mathbf{3}$ is stable in ambient conditions but reacts readily with electrophiles $\left(\mathrm{H}^{+}\right.$and $\left.\mathrm{CO}\right)$.
\end{abstract}

Terminal metal nitride complexes have been highly soughtafter synthetic targets because of their key roles in the catalytic $\mathrm{N}_{2}$ hydrogenation for ammonia production and in $\mathrm{N}$ transfer processes. ${ }^{1}$ Terminal uranium nitride compounds provide molecular analogs of inorganic uranium nitride materials (UN) which are effective catalysts in the Haber-Bosch synthesis of ammonia. ${ }^{2}$ In recent years, few examples of mononuclear borane- ${ }^{3}$ or alkali ion- ${ }^{4}$ capped terminal nitrides and several multimetallic nitrides have been synthesized ${ }^{1 \mathrm{~g}, 5}$ which have demonstrated high reactivity towards small molecule activation and functionalization. ${ }^{1 \mathrm{~g},} 6 \mathrm{How}$ ever, the synthesis of bona fide terminal U(V) and U(VI) nitrides remains limited to a single polydentate ligand system (Tren ${ }^{\mathrm{TIPS}}$ : $\left.\left\{\mathrm{N}\left(\mathrm{CH}_{2} \mathrm{CH}_{2} \mathrm{NSi}^{\mathrm{P}} \mathrm{Pr}_{3}\right)_{3}\right\}^{3-}\right) .^{4 \mathrm{~b}, 7}$

Photolysis of metal azide complexes has been the most effective route for the synthesis of metal nitrides. This route has allowed the synthesis of terminal metal nitrides in transition metal chemistry, ${ }^{1 \mathrm{c}, 1 \mathrm{~h}, 8,9}$ but has so far failed to yield a stable terminal uranium nitride complex. More generally, the photochemistry of organometallic actinide complexes remains limited to a small handful of studies, most of them going back to 40 years ago. ${ }^{10}$

Particularly relevant to the work here is the first report of a putative terminal U(VI) nitride intermediate that was generated in photolytic conditions but could not be isolated because it readily effected the $\mathrm{C}-\mathrm{H}$ activation of the supporting cyclopentadienyl ligand. ${ }^{11}$ Photolysis of uranium(IV) azide complexes with bulky amide supporting ligands $\mathrm{s}^{6 \mathrm{~h}, 7 \mathrm{~b}}$ also failed to produce isolable terminal U(VI) nitrides, but resulted in the intramolecular insertion of the nitride intermediate in the ligand framework. This led to the conclusion that it may not be possible to prepare terminal uranium nitrides by photolysis of azides due to the low stability of transient nitrides under the high energy photolytic conditions.

Here we report the second example of a terminal U(VI) nitride, [U(OSi $\left.\left.\left(\mathrm{O}^{\mathrm{t}} \mathrm{Bu}\right)_{3}\right)_{4}(\mathrm{~N})\right], 3$, and show that by a careful tuning of the reaction conditions it is possible to prepare 3 by photolysis of the sterically demanding terminal U(IV) azide $\left[\mathrm{NBu}_{4}\right]\left[\mathrm{U}\left(\mathrm{OSi}\left(\mathrm{O}^{\mathrm{t} B u}\right)_{3}\right)_{4}\left(\mathrm{~N}_{3}\right)\right],[\mathbf{N B u} 4]-2$. Notably, the fast conversion of $\left[\mathrm{NBu}_{4}\right]-\mathbf{2}$ into the nitride $\mathbf{3}$ under irradiation renders possible its isolation, and suggests that previous attempts failed to produce isolable terminal U(VI) nitrides because the photolysis of the U(IV) azide precursor required longer times (24-80 hours). ${ }^{6 \mathrm{~h}, 11}$

In order to investigate the photolysis of U(IV) azide complexes, we first pursued the synthesis of an anionic U(IV)terminal azide supported by four alkoxy(siloxide) ligands $\left[\mathrm{U}\left(\mathrm{N}_{3}\right)\left(\mathrm{OSi}\left(\mathrm{O}^{\mathrm{t}} \mathrm{Bu}\right)_{3}\right)_{4}\right]^{-}$(Scheme S1). The bulky environment provided by the four siloxides was chosen for its ability to stabilize a terminal $U(V)$ oxide by preventing the formation of oxide bridged multimetallic species. ${ }^{12}$ 
In previous studies we isolated and crystallographically characterized the complex $\left[\mathrm{K}(18 \mathrm{c} 6)\left(\mu-\mathrm{N}_{3}\right) \mathrm{U}\left(\mathrm{OSi}\left(\mathrm{O}^{\mathrm{t}} \mathrm{Bu}\right)_{3}\right)_{4}\right]$, [K(18c6)]-2 (18c6= 18-crown-6) which formed, together with a bis-nitride diuranium(V) complex and other products, from the reaction of the U(III) complex $[\mathrm{K}(18 \mathrm{c} 6)]\left[\mathrm{U}\left(\mathrm{OSi}\left(\mathrm{O}^{\mathrm{t}} \mathrm{Bu}\right)_{3}\right)_{4}\right]$ with $\mathrm{CsN}_{3} .^{5 \mathrm{~g}}$ This reaction failed to yield a terminal nitride and the U(IV) azide [K(18c6)]-2 could not be reproducibly prepared from this route. Uranium(IV) azides were shown to provide a more reliable route to terminal uranium(V) nitrides for the Tren ${ }^{\text {TIPS }}$ system. ${ }^{\mathrm{b}}$

Therefore, we set out to prepare the U(IV) azide $\left[\left(\mathrm{N}_{3}\right) \mathrm{U}\left(\mathrm{OSi}\left(\mathrm{O}^{\mathrm{t}} \mathrm{Bu}\right)_{3}\right)_{4}\right]^{-}$by reacting the homoleptic $\mathrm{U}(\mathrm{IV})$ tetrasiloxide complex $\left[\mathrm{U}\left(\mathrm{OSi}\left(\mathrm{O}^{\mathrm{t}} \mathrm{Bu}\right)_{3}\right)_{4}\right],{ }^{5 \mathrm{~g}} \mathbf{1}$ with different azides.

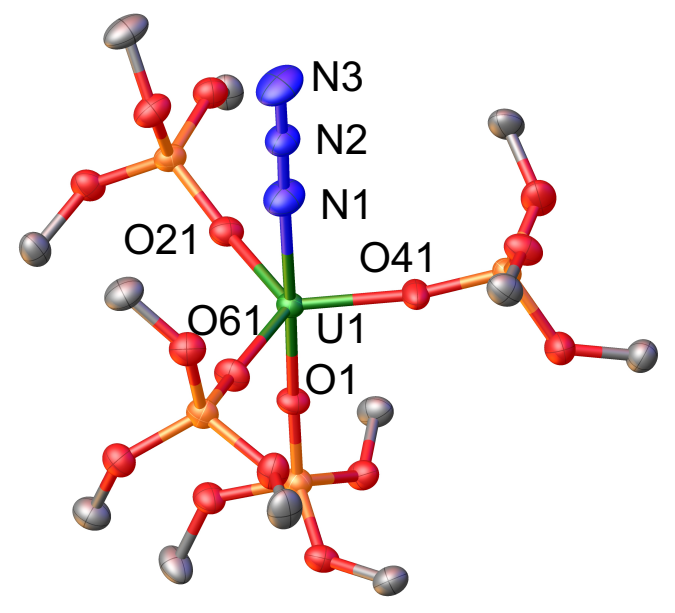

Figure 1. Thermal ellipsoid plot of the anion $\left[\mathrm{U}\left(\mathrm{OSi}\left(\mathrm{O}^{\mathrm{t}} \mathrm{Bu}\right)_{3}\right)_{4}\left(\mathrm{~N}_{3}\right)\right]-$ in $\left[\mathbf{N B u}_{4}\right]-2$ at $50 \%$ probability. The ${ }^{\mathrm{t}} \mathrm{Bu}$ moieties have been omitted for clarity in all figures.

The reaction of 1 with $\mathrm{KN}_{3}$ resulted in intractable mixtures independently of the reaction temperature. In contrast, the addition of $\mathrm{NBu}_{4} \mathrm{~N}_{3}$ to a solution of $\mathbf{1}$ in $d_{8}$-thf at room temperature led to the formation of a single new species resonating at $0.33 \mathrm{ppm}$. Cooling down the reaction mixture in toluene at $-80^{\circ} \mathrm{C}$ afforded light blue single crystals of the ion pair complex $\left[\mathrm{NBu}_{4}\right]\left[\mathrm{U}\left(\mathrm{OSi}\left(\mathrm{O}^{\mathrm{t} B u}\right)_{3}\right)_{4}\left(\mathrm{~N}_{3}\right)\right],\left[\mathrm{NBu}_{4}\right]-2$ in $74 \%$ yield (Scheme S1). The synthesis of the K(18c6) analogue $\left[\mathrm{K}(18 \mathrm{c} 6)\left(\mu-\mathrm{N}_{3}\right) \mathrm{U}\left(\mathrm{OSi}\left(\mathrm{O}^{\mathrm{t}} \mathrm{Bu}\right)_{3}\right)_{4}\right],[\mathbf{K}(\mathbf{1 8 c 6})]-2$ in analytically pure form required performing the reaction between $\mathbf{1}$ and $[\mathrm{K}(18 \mathrm{c} 6)] \mathrm{N}_{3}$ in thf at $-80^{\circ} \mathrm{C}$ for $5 \mathrm{~h}$. Crystallization from toluene at $-40^{\circ} \mathrm{C}$ affords the crystalline complex [K(18c6)]2 in $72 \%$ yield. The isolated complexes [NBu $4-2$ and [K(18c6)]-2 are both stable in a thf or toluene solution at RT for at least one week or at $70^{\circ} \mathrm{C}$ for at least 3 days. Moreover, ${ }^{1} \mathrm{H}$ NMR studies of $[\mathbf{K}(\mathbf{1 8 c 6})]-2$ in $d_{8}$-thf and $d_{8}$-toluene showed that the $[\mathrm{K}(18 \mathrm{c} 6)]^{+}$cation remains bound to the azide in both solvents. The 2.2.2. cryptand (crypt) analogue $\left[\mathrm{K}(\mathrm{crypt})\left(\mu-\mathrm{N}_{3}\right) \mathrm{U}\left(\mathrm{OSi}\left(\mathrm{O}^{\mathrm{t}} \mathrm{Bu}\right)_{3}\right)_{4}\right]$, [K(crypt)]-2 could only be prepared in situ upon reaction of $\mathbf{1}$ with excess (5 equivs.) of $[\mathrm{K}(\mathrm{crypt})] \mathrm{N}_{3}$ in toluene or thf to avoid release of the bound azide. Light blue crystals of [K(crypt)]-2 were obtained from a concentrated reaction mixture in hexane at $40^{\circ} \mathrm{C}$.
The molecular structures of complexes [K(crypt)]-2 (Figure S55) and [NBu 4 ]-2 (Figure 1) all show a similar coordination environment and only differ in the nature of the counterion. Both $[\mathrm{K}(\mathrm{crypt})]^{+}$and $[\mathrm{K}(18 \mathrm{c} 6)]^{+}$cations bind the azide ligand in an end-to-end fashion in [K(crypt)]-2 and $[\mathbf{K}(\mathbf{1 8 c 6})]-2$, while [ $\left.\mathbf{N B u}_{4}\right]-2$ consists of a separated ion pair. The N1-K1 distance of 3.3(1) ̊ in [K(crypt)]-2 is much longer than the one observed for [K(18c6)]-25g of $2.562(6) \AA$. This difference is in line with the cryptand being bulkier than the crown ether and is likely to be the origin of the different stability of the uranium-bound azides. The values of the U1-N1 in the complexes [NBu4]-2, [K(crypt)]-2, and [K(18c6)]-2, of 2.375(4) $\AA, 2.379(6) \AA$, and 2.351(7) respectively, are on the longer end of the range of values found in previously reported U(IV) azide complexes (2.142(5) $\AA-2.442(6), \AA$ ). ${ }^{7 b, 11,13}$ The N-N bond distances are very close to each other in all the three complexes $(1.187(5)$ and 1.165(6) $\AA$ for [NBu 4$]-2,1.18(1)$ and 1.145(6) $\AA$ for [K(crypt)]-2, and 1.180(9) and 1.226(11) Å for [K(18c6)]2).

These values do not necessarily suggest a low activation of the azide moiety. Notably, a similarly long U-N distance and similar equivalency in $\mathrm{N}-\mathrm{N}$ distances were found in the terminal U(IV) azide supported by the bulky Tren ${ }^{\text {TIPS }}$ ligand, which readily undergo photolysis to yield a cyclometallated amide trough a nitride intermediate. ${ }^{7 \mathrm{~b}}$ Moreover, the higher value found for the $v_{a s}\left(\mathrm{~N}_{3}\right)$ of $[\mathbf{K}(\mathbf{1 8 c 6})]-2\left(2096 \mathrm{~cm}^{-1}\right)$ compared to $\left[\mathrm{NBu}_{4}\right]-2\left(2057 \mathrm{~cm}^{-1}\right)$ and $\left(2096 \mathrm{~cm}^{-1}\right)$ indicates a higher degree of activation.

The photolysis of $d_{8}$-thf solutions of $\left[\mathbf{N B u}_{4}\right]-2$ with a UV lamp (253.7 nm) for 30 minutes yielded an orange solution whose ${ }^{1} \mathrm{H}$ NMR spectrum showed only one major species with a resonance at $1.44 \mathrm{ppm}$. Single crystals of the terminal nitride complex $\left[\mathrm{NBu}_{4}\right]\left[\mathrm{U}\left(\mathrm{OSi}\left(\mathrm{O}^{\mathrm{t}} \mathrm{Bu}\right)_{3}\right)_{4}(\mathrm{~N})\right], 3$ were obtained in $70 \%$ yield from a 1:1 toluene/hexane mixture at $25^{\circ} \mathrm{C}$. Longer irradiation times $(8 \mathrm{~h})$ resulted in the full transformation of $\mathbf{3}$ into unidentified products.

Complex 3 shows remarkable stability in thf and toluene under ambient light for up to three weeks. As a comparison, 1 week was indicated as the half-life of the only other reported terminal U(VI) nitride [U(Tren $\left.{ }^{\text {TIPS }}\right) \mathrm{N}$ ] in a toluene solution. ${ }^{\text {b }}$

However, photolysis of thf and toluene solutions of $\mathbf{3}$ with a UV lamp (253.7 $\mathrm{nm}$ ) resulted in the appearance of the same unidentified decomposition products after $5 \mathrm{~h}$ and 30 minutes respectively, showing that the photolytic stability of $\mathbf{3}$ varies with the solvent nature.

Photolysis of $d_{8}$-toluene solutions of $\left[\mathbf{N B u}_{4}\right]-2$ with a UV lamp (253.7 $\mathrm{nm}$ ) for 2 to $5 \mathrm{~h}$ showed the simultaneous progressive formation of $\mathbf{3}$ and other decomposition products, also formed by photolysis of $\mathbf{3}$ in toluene, rendering impossible the isolation of the nitride $\mathbf{3}$ in these conditions. These results show that both, the photochemical stability of the nitride $\mathbf{3}$, and its rate of formation from the azide vary with the solvent, rendering its choice crucial for the isolation of the nitride. Notably, in thf the formation of the nitride from the azide is much faster than its decomposition, allowing its clean formation and isolation. We also became interested in 
investigating the potential effects of cations on the photochemical stability of the nitride and on the reactivity of the terminal azide.

Scheme 1. Synthesis of the terminal nitride complex 3. $\left(\mathrm{OSi}=\operatorname{OSi}\left(\mathrm{O}^{\mathrm{t}} \mathrm{Bu}\right)_{3}\right)$.

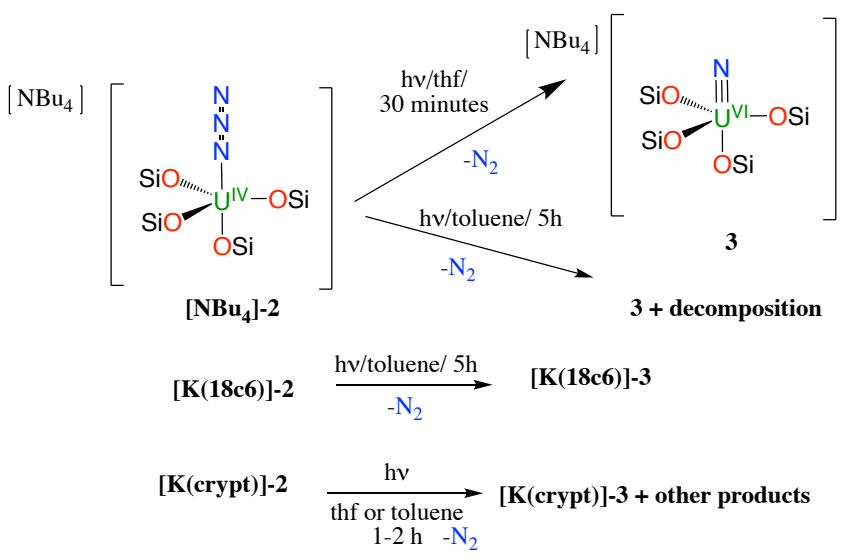

${ }^{1} \mathrm{H}$ NMR studies showed that the addition of excess $(10$ equivs.) [K(18c6)]I to complex 3 in toluene results in the formation of a capped nitride, [K(18c6)]-3, which is stable in toluene under irradiation (253.7 nm) for $5 \mathrm{~h}$. These results indicate a significantly higher photochemical stability of the capped nitride compared to 3 . In contrast, the addition of excess [K(crypt)] I to $\mathbf{3}$ did not affect its decomposition rate under irradiation, suggesting that labile binding of $[\mathrm{K}(\mathrm{crypt})]^{+}$does not enhance the photochemical stability of the nitride.

${ }^{1} \mathrm{H}$ NMR studies showed that the photolysis of $d_{8}$-toluene solutions of [K(18c6)]-2 with a UV lamp (253.7 nm) afforded the clean formation of [K(18c6)]-3, which is complete after $5 \mathrm{~h}$ (Scheme 1). Thus, although the formation of the nitride from the $[\mathrm{K}(18 \mathrm{c} 6)]$-capped azide is slow, as found for the uncapped [ $\left.\mathrm{NBu}_{4}\right]-\mathbf{2}$ azide in toluene, the increased stability of the [K(18c6)]-capped nitride compared to 3 renders possible its clean formation in toluene.

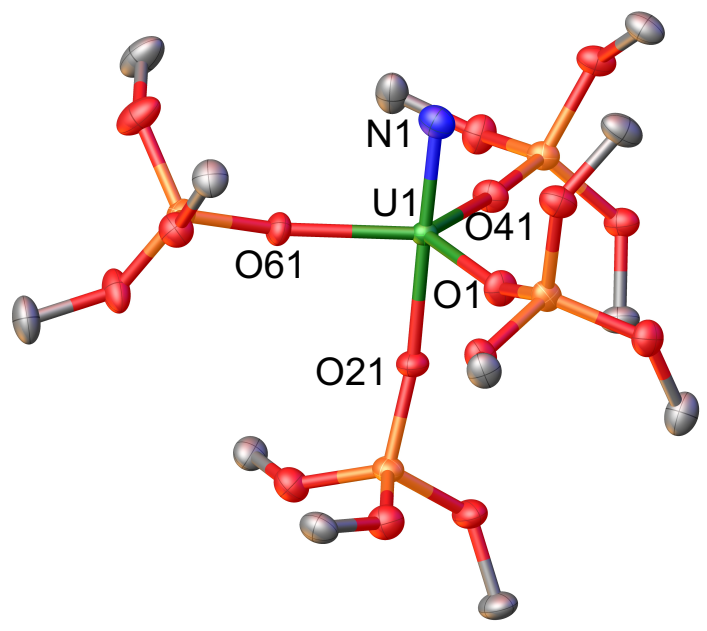

Photolysis of $d_{8}$-toluene and $d_{8}$-thf solutions of [K(crypt)]2 led in both cases to mixtures of [K(crypt)]-2, [K(crypt)]3, and its decomposition products (Scheme 1). The presence of cryptand bound to the azide results in a slower $\mathrm{N}_{2}$ elimination compared to the uncapped azide [NBu $4-2$ rendering impossible the isolation of the nitride product in these conditions.

Thus, capping alkali ions can increase the stability of terminal nitride but also decrease the rate of the dinitrogen release. Thus the counterion choice is key in the photochemical synthesis of terminal and capped nitrides.

Compound 3 represents the first example of an isolated terminal uranium nitride complex generated photochemically. The molecular structure of the $\left[\mathrm{U}\left(\mathrm{OSi}\left(\mathrm{O}^{\mathrm{t}} \mathrm{Bu}\right)_{3}\right)_{4}(\mathrm{~N})\right]^{-}$anion (Figure 2), presents the uranium in a slightly distorted trigonal bipyramidal geometry, with three siloxides lying on the equatorial plane and the axial positions occupied by the nitride ligand and a fourth siloxide ligand. The U1-021 distance at 2.073(1) $\AA$ is approximately 6\% smaller compared to the mean value of the equatorial $\mathrm{U}-\mathrm{O}_{\text {siloxide }}$ bond distances $(2.20(3) \AA)$. This is indicative of an Inverse Trans Influence (ITI), often manifested in high valent $f$-element complexes. ${ }^{14,7 \mathrm{~b}}$ The U1-N1 bond distance (1.769 (2) $\AA$ ) is slightly shorter than the U-nitride distance reported for [U(TrenTIPS)N] (1.799(7) Å) 7b and compares well with the value calculated for the matrix-isolated terminal nitride complex $\left[\mathrm{UNF}_{3}\right](1.76 \AA) \cdot{ }^{15}$

Complex 3 reacts with $\mathrm{H}^{+}$sources to afford ammonia. A $100 \%$ conversion to $\mathrm{NH}_{4} \mathrm{Cl}$ was observed upon reaction of 3 with excess $\mathrm{HCl}$. Using $\mathrm{H}_{2} \mathrm{O}$ as the proton source yielded $20 \%$ conversion to $\mathrm{NH}_{3}$. This value increased to $56 \%$ when the reaction was carried out in presence of 3 equivalents of CoCp* ${ }_{2}$. Complex 3 was also found to react readily with 1 atm of $\mathrm{CO}$ in thf, yielding the reductive carbonylation product $\left[\mathrm{NBu}_{4}\right]\left[\mathrm{U}\left(\mathrm{OSi}\left(\mathrm{O}^{\mathrm{t} B u}\right)_{3}\right)_{4}(\mathrm{NCO})\right], 4$ in $80 \%$ yield (Scheme $2)$.

Scheme 2. Reductive carbonylation of 3 to yield 4 and formation of $\mathrm{Me}_{3} \mathrm{SiNCO}$. $\left(\mathrm{OSi}=\mathrm{OSi}\left(\mathrm{O}^{\mathrm{t}} \mathrm{Bu}\right)_{3}\right)$.

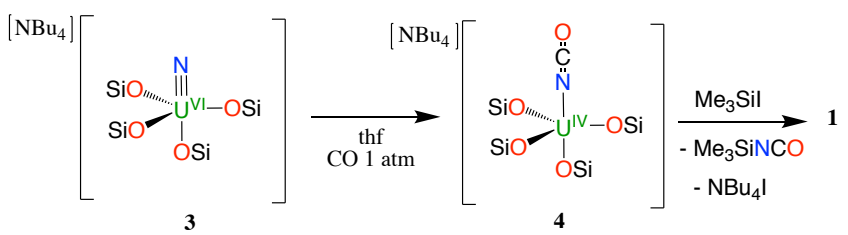

The solid-state structure of $\mathbf{4}$ (Figure 3), shows, together with IR and ${ }^{13} \mathrm{C}$ NMR spectra (see Supporting Information), that the nitride group in $\mathbf{3}$ has been converted into an isocyanate ligand. The U1-N1 bond distance of 2.406(2) Å falls in the range of previously reported U(IV)-isocyanate complexes $(2.270-2.559 \AA) .6 \mathrm{~d}, 16$.

Figure 2. Thermal ellipsoid plot of the anion $\left[\mathrm{U}\left(\mathrm{OSi}\left(\mathrm{O}^{\mathrm{t}} \mathrm{Bu}\right)_{3}\right)_{4}(\mathrm{~N})\right]^{-}$in $\mathbf{3}$ at $50 \%$ probability. 


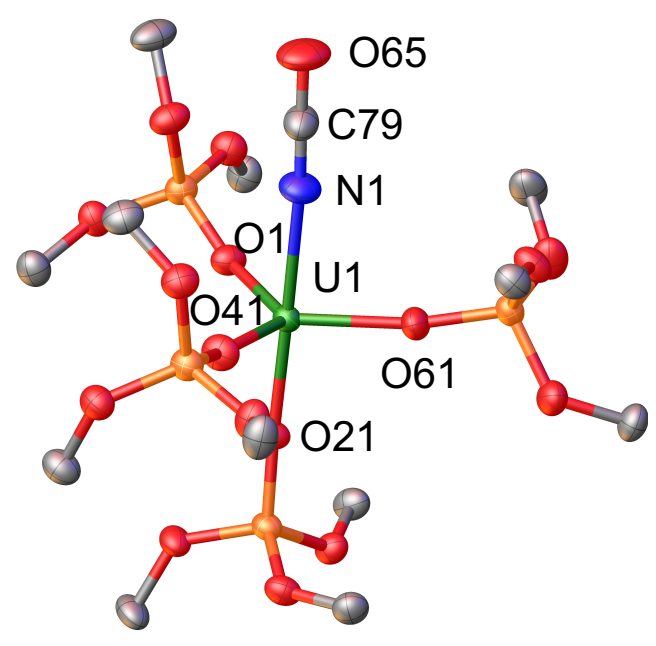

Figure 3. Thermal ellipsoid plot of the anion $\left[\mathrm{U}\left(\mathrm{OSi}\left(\mathrm{O}^{\mathrm{t}} \mathrm{Bu}\right)_{3}\right)_{4}(\mathrm{NCO})\right]^{-}$in 4 at $50 \%$ probability.

A similar two-electrons reduction by $\mathrm{CO}$ was reported for $\mathrm{U}(\mathrm{V})$ and $\mathrm{U}(\mathrm{VI})$ terminal nitride species ${ }^{6 \mathrm{f}}$ as well as for the $\mathrm{U}(\mathrm{V})$ bis- $\mu$-nitride complex $\left[\mathrm{K}_{2}\left\{\mathrm{U}\left(\mathrm{OSi}\left(\mathrm{O}^{\mathrm{t}} \mathrm{Bu}\right)_{3}\right)_{2}(\mu-\mathrm{N})\right\}_{2}\right]^{.5 a}$ However, the U(VI) terminal nitride complex, [U(TrenTIPS)N], reacts with CO over the course of $16 \mathrm{~h}$ while complex 3 reacts immediately with $\mathrm{CO}$. The addition of 1 equiv. of $\mathrm{SiMe}_{3} \mathrm{I}$ to $\left[\mathrm{NBu}_{4}\right]\left[\mathrm{U}\left(\mathrm{OSi}\left(\mathrm{O}^{\mathrm{t}} \mathrm{Bu}\right)_{3}\right)_{4}(\mathrm{NCO})\right], 4$ led to the formation of [U(OSi $\left.\left.\left(\mathrm{O}^{\mathrm{t}} \mathrm{Bu}\right)_{3}\right)_{4}\right], \mathbf{1}$ as the main U-containing species and of $\mathrm{SiMe}_{3} \mathrm{NCO}$ as confirmed by ${ }^{1} \mathrm{H},{ }^{13} \mathrm{C}$ NMR and IR ( $V_{\text {as }}(\mathrm{NCO}) 2162 \mathrm{~cm}^{-1}$ ) spectroscopy. The formation of $\left[\mathrm{U}\left(\mathrm{OSi}\left(\mathrm{O}^{\mathrm{t}} \mathrm{Bu}\right)_{3}\right)_{4}\right], \mathbf{1}$ allows to close the synthetic cycle for the formation of $\mathrm{SiMe}_{3} \mathrm{NCO}$ from $\mathrm{NBu}_{4} \mathrm{~N}_{3}$ and $\mathrm{CO}$.

In summary we have photochemically generated and characterized a terminal uranium(VI) nitride which is stable under ambient conditions but displays high reactivity towards electrophiles undergoing reductive carbonylation to yield cyanate. Photolysis studies of three sterically demanding anionic uranium azide complexes demonstrated that facile release of dinitrogen occurs in all conditions, but clean formation of the nitride requires a careful tailoring of the solvent and counterion. The use of an anionic azide precursor allows a fine tuning of the photochemical generation of the terminal uranium nitride.

\section{ASSOCIATED CONTENT}

\section{Supporting Information}

X-ray data (CIF), experimental procedures, NMR spectra, IR and UV spectroscopic data (PDF).

"This material is available free of charge via the Internet at http://pubs.acs.org.".

\section{AUTHOR INFORMATION}

\section{Corresponding Author}

*marinella.mazzanti@epfl.ch.

\section{Author Contributions}

The manuscript was written through contributions of all authors. / All authors have given approval to the final version of the manuscript.

\section{ACKNOWLEDGMENT}

We thank the Swiss National Science Foundation (178793) for financial support and Farzaneh Fadaei-Tirani for contribution to X-ray data analyses.

\section{REFERENCES}

(1. (a) Kim, S.; Loose, F.; Chirik, P. J., Beyond Ammonia: Nitrogen-Element Bond Forming Reactions with Coordinated Dinitrogen. Chem. Rev. 2020, 120, 5637-5681; (b) Chalkley, M. J.; Drover, M. W.; Peters, J. C., Catalytic $\mathrm{N}_{2}$-to- $\mathrm{NH}_{3}$ (or $-\mathrm{N}_{2} \mathrm{H}_{4}$ ) Conversion by Well-Defined Molecular Coordination Complexes. Chem. Rev. 2020, 120, 5582-5636; (c) Suarez, A. I. O.; Lyaskovskyy, V.; Reek, J. N. H.; van der Vlugt, J. I.; de Bruin, B., Complexes with Nitrogen-Centered Radical Ligands: Classification, Spectroscopic Features, Reactivity, and Catalytic Applications. Angew. Chem.Int.Ed. Engl. 2013, 52, 12510-12529; (d) Askevold, B.; Nieto, J. T.; Tussupbayev, S.; Diefenbach, M.; Herdtweck, E.; Holthausen, M. C.; Schneider, S., Ammonia formation by metal-ligand cooperative hydrogenolysis of a nitrido ligand. Nat. Chem. 2011, 3, 532-537; (e) Doyle, L. R.; Wooles, A. J.; Liddle, S. T., Bimetallic Cooperative Cleavage of Dinitrogen to Nitride and Tandem Frustrated Lewis Pair Hydrogenation to Ammonia. Angew. Chem. Int. Ed. Engl. 2019, 58, 6674-6677; (f) Thompson, N. B.; Green, M. T.; Peters, J. C., Nitrogen Fixation via a Terminal Fe(IV) Nitride. J. Am. Chem. Soc. 2017, 139, 15312-15315; (g) Falcone, M.; Chatelain, L.; Scopelliti, R.; Zivkovic, I.; Mazzanti, M., Nitrogen reduction and functionalization by a multimetallic uranium nitride complex. Nature 2017, 547, 332-335; (h) Sun, J.; Abbenseth, J.; Verplancke, H.; Diefenbach, M.; de Bruin, B.; Hunger, D.; Würtele, C.; van Slageren, J.; Holthausen, M. C.; Schneider, S., A platinum(II) metallonitrene with a triplet ground state. Nat. Chem. 2020, 12, 1054-1059.

\section{Haber, F. Ger. Pat. DE229126. 1909.}

3. (a) Boreen, M. A.; Rao, G. D.; Villarreal, D. G.; Watt, F. A.; Britt, R. D.; Hohloch, S.; Arnold, J., Lewis acid capping of a uranium(V) nitride via a uranium(III) azide molecular square. Chem. Commun. 2020, 56, 4535-4538; (b) Fox, A. R.; Cummins, C. C., Uranium-Nitrogen Multiple Bonding: The Case of a Four-Coordinate Uranium(VI) Nitridoborate Complex. J. Am. Chem. Soc. 2009, 131, 5716-5717.

4 synthesis and characterisation of $\mathrm{U}(\mathrm{V})$ oxo and nitrido complexes. Chem. Sci. 2016, 7, 4624-4632; (b) King, D. M.; Cleaves, P. A.; Wooles, A. J.; Gardner, B. M.; Chilton, N. F.; Tuna, F.; Lewis, W.; McInnes, E. J. L.; Liddle, S. T., Molecular and electronic structure of terminal and alkali metal-capped uranium(V) nitride complexes. Nat. Commun. 2016, 7 (13773).

5. (a) Barluzzi, L.; Chatelain, L.; Fadaei-Tirani, F.; Zivkovic, I.; Mazzanti, M., Facile N-functionalization and strong magnetic communication in a diuranium(V) bis-nitride complex. Chem. Sci. 2019, 10, 3543 - 3555; (b) King, D. M.; Liddle, S. T., Progress in molecular uranium-nitride chemistry. Coord. Chem. Rev. 2014, 266, 2 15; (d) Hayton, T. W., Recent developments in actinide-ligand multiple bonding. Chem. Commun. 2013, 49, 2956-2973; (c) Evans, W. J.; Kozimor, S. A.; Ziller, J. W., Molecular octa-uranium rings with alternating nitride and azide bridges. Science 2005, 309, 1835-1838; (d) Korobkov, I.; Gambarotta, S.; Yap, G. P. A., A highly reactive uranium complex supported by the calix 4 tetrapyrrole tetraanion affording dinitrogen cleavage, solvent deoxygenation, and polysilanol depolymerization. Angew. Chem. Int. Ed. Engl. 2002, 41, 3433-3436; (e) Fortier, S.; Wu, G.; Hayton, T. W., Synthesis of a Nitrido- 
Substituted Analogue of the Uranyl Ion, $\mathrm{N}=\mathrm{U}=\mathrm{O}(+)$. J. Am. Chem. Soc. 2010, 132, 6888-6889; (f) Fox, A. R.; Arnold, P. L.; Cummins, C. C., Uranium Nitrogen Multiple Bonding: Isostructural Anionic, Neutral, and Cationic Uranium Nitride Complexes Featuring a Linear $\mathrm{U}=\mathrm{N}=\mathrm{U}$ Core. J. Am. Chem. Soc. 2010, 132, 3250-3251; (g) Camp, C.; Pecaut, J.; Mazzanti, M., Tuning Uranium-Nitrogen Multiple Bond Formation with Ancillary Siloxide Ligands. J. Am. Chem. Soc. 2013, 135, 1210112111; (h) Maria, L.; Santos, I. C.; Sousa, V. R.; Marcalo, J., Uranium(III) Redox Chemistry Assisted by a Hemilabile Bis(phenolate) Cyclam Ligand: Uranium-Nitrogen Multiple Bond Formation Comprising a trans $-\{\mathrm{RN}=\mathrm{U}(\mathrm{VI})=\mathrm{NR}\}(2+)$ Complex. Inorg . Chem. 2015, 54, 9115-9126; i) Chatelain, L.; Scopelliti, R.; Mazzanti, M., Synthesis and Structure of Nitride-Bridged Uranium(III) Complexes. J. Am. Chem. Soc. 2016, 138, 1784-1787; i) Du, J.; King, D. M.; Chatelain, L.; Tuna, F.; McInnes, E. J. L.; Wooles, A. J.; Maron, L.; Liddle, S. T., Thorium- and Uranium-Azide Reductions: A Transient Dithorium-Nitride Versus Isolable Diuranium-Nitrides. Chem. Sci. 2019, 10, 3738-3745.

6. (a) Palumbo, C. T.; Scopelliti, R.; Zivkovic, I.; Mazzanti, M., C-H Bond Activation by an Isolated Dinuclear U(III)/U(IV) Nitride. J. Am. Chem. Soc. 2020, 142, 3149-3157; (b) Falcone, M.; Poon, L. N.; Tirani, F. F.; Mazzanti, M., Reversible Dihydrogen Activation and Hydride Transfer by a Uranium Nitride Complex. Angew. Chem. Int. Ed. Engl. 2018, 57, 3697-3700; (c) Falcone, M.; Kefalidis, C. E.; Scopelliti, R.; Maron, L.; Mazzanti, M., Facile CO Cleavage by a Multimetallic $\mathrm{CsU}_{2}$ Nitride Complex. Angew. Chem. Int Ed. Engl. 2016, 55, 12290-12294; (d) Falcone, M.; Chatelain, L.; Mazzanti, M., Nucleophilic Reactivity of a Nitride-Bridged Diuranium(IV) Complex: $\mathrm{CO}_{2}$ and $\mathrm{CS}_{2}$ Functionalization. Angew. Chem. Int. Ed. Engl. 2016, 55, 4074-4078; (e) Chatelain, L.; Louyriac, E.; Douair, I.; Lu, E. L.; Tuna, F.; Wooles, A. J.; Gardner, B. M.; Maron, L.; Liddle, S. T., Terminal uranium(V)-nitride hydrogenations involving direct addition or Frustrated Lewis Pair mechanisms. Nat. Commun. 2020, 11 (337); (f) Cleaves, P. A.; King, D. M.; Kefalidis, C. E.; Maron, L.; Tuna, F.; McInnes, E. J. L.; McMaster, J.; Lewis, W.; Blake, A. J.; Liddle, S. T., Two-Electron Reductive Carbonylation of Terminal Uranium(V) and Uranium(VI) Nitrides to Cyanate by Carbon Monoxide. Angew. Chem. Int. Ed. Engl. 2014, 53, 10412-10415; (g) Mullane, K. C.; Ryu, H.; Cheisson, T.; Grant, L. N.; Park, J. Y.; Manor, B. C.; Carroll, P. J.; Baik, M. H.; Mindiola, D. J.; Schelter, E. J., C-H Bond Addition across a Transient Uranium-Nitrido Moiety and Formation of a Parent Uranium Imido Complex. J. Am. Chem. Soc. 2018, 140, 11335-11340; (h) Yadav, M.; Metta-Magana, A. J.; Fortier, S., Intra- and intermolecular interception of a photochemically generated terminal uranium nitride. Chem. Sci. 2020, 11, 2381-2387.

$7 . \quad$ (a) King, D. M.; Tuna, F.; McInnes, E. J. L.; McMaster, J.; Lewis, W.; Blake, A. J.; Liddle, S. T., Synthesis and Structure of a Terminal Uranium Nitride Complex. Science 2012, 337, 717-720; (b) King, D. M.; Tuna, F.; McInnes, E. J. L.; McMaster, J.; Lewis, W.; Blake, A. J.; Liddle, S. T., Isolation and characterization of a uranium(VI)-nitride triple bond. Nat. Chem. 2013, 5, 482-488.

8. (a) Scheibel, M. G.; Askevold, B.; Heinemann, F. W.; Reijerse, E. J.; de Bruin, B.; Schneider, S., Closed-shell and open-shell square-planar iridium nitrido complexes. Nat. Chem. 2012, 4, 552-558; (b) Atienza, C. C. H.; Bowman, A. C.; Lobkovsky, E.; Chirik, P. J., Photolysis and Thermolysis of Bis(imino)pyridine Cobalt Azides: C-H Activation from Putative Cobalt Nitrido Complexes. J. Am. Chem. Soc. 2010, 132, 16343-16345; (c) Vogel, C.; Heinemann, F. W.; Sutter, J.; Anthon, C.; Meyer, K., An iron nitride complex. Angew. Chem. Int. Ed. Engl. 2008, 47, 2681-2684; (d) Scepaniak, J. J.; Fulton, M. D.; Bontchev, R. P.; Duesler, E. N.; Kirk, M. L.; Smith, J. M., Structural and spectroscopic characterization of an electrophilic iron nitrido complex. J. Am. Chem. Soc. 2008, 130, 10515-10516; (e) Berry, J. F.; Bill, E.; Bothe, E.; George, S. D.; Mienert, B.; Neese, F.; Wieghardt,
K., An octahedral coordination complex of iron(VI). Science 2006, 312, 1937-1941.

9. (a) Camp, C.; Grant, L. N.; Bergman, R. G.; Arnold, J., Photo-activation of $\mathrm{d}(0)$ niobium imido azides: en route to nitrido complexes. Chem. Commun. 2016, 52, 5538-5541; (b) Zolnhofer, E. M.; Kaess, M.; Khusniyarov, M. M.; Heinemann, F. W.; Maron, L.; van Gastel, M.; Bill, E.; Meyer, K., An Intermediate Cobalt(IV) Nitrido Complex and its N-Migratory Insertion Product. J. Am. Chem. Soc. 2014, 136, 15072-15078.

10. (a) Bruno, J. W.; Kalina, D. G.; Mintz, E. A.; Marks, T. J., Mechanistic study of photoinduced beta-hydride elimination - the facile photochemical-synthesis of low-valent thorium and uranium organometallics. J. Am. Chem. Soc. 1982, 104, 1860-1869; (b) Kalina, D. G.; Marks, T. J.; Wachter, W. A., Photochemical-Synthesis of lowvalent organothorium complexes - evidence for photoinduced betahydride elimination. J. Am. Chem. Soc. 1977, 99, 3877-3879; (c) Magnall, R.; Balazs, G.; Lu, E. L.; Kern, M.; van Slageren, J.; Tuna, F.; Wooles, A. J.; Scheer, M.; Liddle, S. T., Photolytic and Reductive Activations of 2-Arsaethynolate in a Uranium-Triamidoamine Complex: Decarbonylative Arsenic-Group Transfer Reactions and Trapping of a Highly Bent and Reduced Form. Chem. Eur. J. 2019, 25, 14246-14252; (d) Gardner, B. M.; Patel, D.; Lewis, W.; Blake, A. J.; Liddle, S. T., Photochemically Promoted Bond-Cleavage and -Capture in a Diazomethane Derivative of a Triamidoamine Uranium(IV) Complex. Angew. Chem. Int. Ed. Engl. 2011, 50, 10440-10443;(e) Berthet, J. C.; Lemarechal, J. F.; Ephritikhine, M., (Eta-5$\left.\mathrm{C}_{5} \mathrm{H}_{4} \mathrm{SiMe}_{3}\right)_{3} \mathrm{UH}$ - the 1st stable organouranium(IV) hydride. J. Chem. Soc. Chem. Commun. 1991, 360-361.

11. Thomson, R. K.; Cantat, T.; Scott, B. L.; Morris, D. E.; Batista, E. R.; Kiplinger, J. L., Uranium azide photolysis results in C$\mathrm{H}$ bond activation and provides evidence for a terminal uranium nitride. Nat. Chem. 2010, 2, 723-729.

12. Cooper, O.; Camp, C.; Pécaut, J.; Kefalidis, C. E.; Maron, L.; Gambarelli, S.; Mazzanti, M., Multimetallic Cooperativity in Uranium-Mediated $\mathrm{CO}_{2}$ Activation. J. Am. Chem. Soc. 2014, 136, 6716-6723.

13. (a) Fortier, S.; Wu, G.; Hayton, T. W., U(IV) and U(V) azide complexes supported by amide or aryloxide ligands. J. Chem. Soc.Dalton Trans. 2010, 39, 352-354; (b) Benaud, O.; Berthet, J.-C.; Thuery, P.; Ephritikhine, M., Iodide, Azide, and Cyanide Complexes of $(\mathrm{N}, \mathrm{C}),(\mathrm{N}, \mathrm{N})$, and $(\mathrm{N}, \mathrm{O})$ Metallacycles of Tetra- and Pentavalent Uranium. Inorg. Chem. 2011, 50, 12204-12214; (c) Crawford, M. J.; Ellern, A.; Mayer, P., $\mathrm{UN}_{21^{3-:}}$ A structurally characterized binary actinide heptaazide anion. Angew. Chem. Int. Ed. Engl. 2005, 44, 78747878 .

14. (a) Kaltsoyannis, N., Computational study of analogues of the uranyl ion containing the $-\mathrm{N}=\mathrm{U}=\mathrm{N}$ - unit: Density functional theory calculations on $\mathrm{UO}_{2}{ }^{2+}, \mathrm{UON}^{+}, \mathrm{UN}_{2}, \mathrm{UO}\left(\mathrm{NPH}_{3}\right)(3+), \mathrm{U}\left(\mathrm{NPH}_{3}\right)(2)(4+)$, $\mathrm{UCl}_{4}\left\{\mathrm{NPR}_{3}\right\}(2)(\mathrm{R}=\mathrm{H}, \mathrm{Me})$, and $\mathrm{UOCl}_{4}\left\{\mathrm{NP}\left(\mathrm{C}_{6} \mathrm{H}_{5}\right)(3)\right\}(-)$. Inorg Chem. 2000, 39, 6009-6017; (b) Kosog, B.; La Pierre, H. S.; Heinemann, F. W.; Liddle, S. T.; Meyer, K., Synthesis of Uranium(VI) Terminal Oxo Complexes: Molecular Geometry Driven by the Inverse Trans-Influence. J. Am. Chem. Soc. 2012, 134, 5284-5289.

15. Andrews, L.; Wang, X.; Lindh, R.; Roos, B. O.; Marsden, C. J., Simple $\mathrm{NUF}_{3}$ and $\mathrm{P} \mathrm{UF}_{3}$ molecules with triple bonds to uranium. Angew. Chem. Int. Ed. Engl. 2008, 47, 5366-5370.

16. Boreen, M. A.; McCabe, K. N.; Lohrey, T. D.; Watt, F. A.; Maron, L.; Hohloch, S.; Arnold, J., Uranium Metallocene Azides, Isocyanates, and Their Borane-Capped Lewis Adducts. Inorg. Chem. 2020, $59,8580-8588$. 


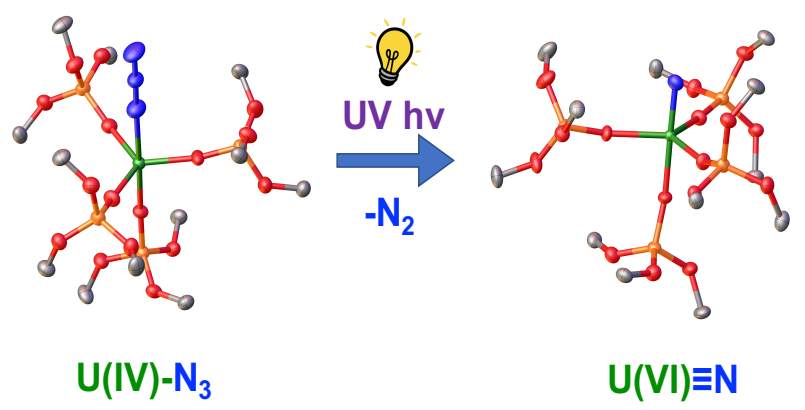

